A N N A LES

\begin{tabular}{l} 
UNIVERSITATIS M A R I A E CURIE-SKŁODOWS K A \\
LUBLIN - POLONIA \\
VOL. XV, 1 \\
\hline
\end{tabular}

Instytut Muzykologii Uniwersytetu Wrocławskiego

Joanna MiklaszewsKa

\title{
Inspiracje Moniuszkowskie w muzyce XX wieku. Opera Pomsta Jontkowa Bolesława Wallek Walewskiego
}

Moniuszko-Based Inspirations in Twentieth-Century Music.

The Opera Pomsta Jontkowa by Bolesław Wallek Walewski

Stanisław Moniuszko wywarł duży wpływ na rozwój opery polskiej w kolejnych dziesięcioleciach. Opery o charakterze narodowym komponowali Władysław Żeleński (1837-1921) i Henryk Jarecki (1846-1918), bezpośrednio zaś do jednej z najsłynniejszych oper Moniuszki nawiązał urodzony we Lwowie, lecz związany przede wszystkim ze środowiskiem muzycznym Krakowa, Bolesław Wallek Walewski (1885-1944) w swojej operze Pomsta Jontkowa. Wallek Walewski był jedną z najważniejszych postaci krakowskiego życia muzycznego w okresie międzywojennym. Jego zasługą było stworzenie w Krakowie działającego przez kilkanaście lat teatru operowego, zorganizowany zaś przezeń chór męski „Echo” zdobył duży rozgłos i uznanie w polskim środowisku muzycznym. Był zatem Walewski znakomitym dyrygentem, zarówno zespołów chóralnych, jak i wokalno-symfonicznych, oraz zasłużonym organizatorem krakowskiego życia muzycznego.

Twórczość i działalność tego niesłusznie zapomnianego dziś kompozytora zasługuje na przyznanie należnego jej miejsca we współczesnej kulturze polskiej. Ważne zadanie w propagowaniu jego muzyki spełniła opublikowana w 1975 roku w Krakowie monografia Leona Świerczka Bolestaw Wallek Walewski ${ }^{1}$,

${ }^{1}$ L. Świerczek, Bolesław Wallek Walewski, Kraków 1975. 
przypomniana w 1971 roku przez Operę Wrocławską po 45 latach od swej poznańskiej prapremiery opera Pomsta Jontkowa oraz wydana w 1992 roku w Paryżu książka Dominiki Porębskiej-Kwaśnik L'Opera Polonais. Halka et La vengeance du Jontek ${ }^{2}$. Wśród prac naukowych na temat muzyki Walewskiego wymienić należy także artykuły Krzysztofa Kostrzewy ${ }^{3}$, Dominiki Porębskiej-Kwaśnik ${ }^{4}$ i Wojciecha Kałamarza ${ }^{5}$. Trzeba również wspomnieć o hasłach poświęconych kompozytorowi, które ukazały się w czołowych encyklopediach i leksykonach muzycznych, polskich i zagranicznych ${ }^{6}$. W 1974 roku twórczość Wallek Walewskiego przypomniana została na sesji popularnonaukowej zorganizowanej przez Towarzystwo Muzyczne w Krakowie, Katedrę Muzykologii UJ oraz Katedrę Teorii Muzyki PWSM w trzydziestą rocznicę jego śmierci?

Ojciec kompozytora, Adolf Walewski, był człowiekiem teatru - aktorem oraz reżyserem teatralnym. Cenił go Stanisław Wyspiański; w 1901 roku Walewski przygotował prapremierowe wystawienie jego Wesela w Teatrze Miejskim w Krakowie ${ }^{8}$, które stało się wielkim wydarzeniem artystycznym. Adolf Walewski był synem radcy namiestnictwa we Lwowie - Adolfa Walka oraz Karoliny z domu Krenth. Zmienił swoje nazwisko rodowe Walek na Walewski, jednak, jak zauważa Leon Świerczek, „,nie dopełnił prawdopodobnie formalności w Urzędzie Stanu Cywilnego, gdyż nazwisko Bolesława brzmi według metryki Walek, w szkole powszechnej Walewski, a na świadectwie maturalnym i w indeksie uniwersyteckim wypisane jest nazwisko Wallek" ". Bolesław przyjął ostatecznie jako swoje oficjalne nazwisko oryginalne, dwuczłonowe nazwisko Wallek Walewski ${ }^{10}$.

${ }^{2}$ D. Quasnik, L'Opera Polonais. Halka et La vengeance du Jontek, Paryż 1992.

${ }^{3}$ K. Kostrzewa, Muzyka chóralna Bolesława Wallek-Walewskiego, [w:] Krakowska szkoła kompozytorska 1888-1988, red. T. Malecka, Kraków 1992, s. 47-66.

${ }^{4}$ D. Porębska-Kwaśnik, Symbole i przekazy pokoju w polskiej muzyce dramatycznej w pierwszej połowie XX w. (1901-1926), [w:] eadem, Polska muzyka dramatyczna, t. 5, Toruń 2007, s. 5-18. Artykuł ten zawiera m.in. analizę konfliktu społecznego w Pomście Jontkowej.

${ }^{5}$ W. Kałamarz, Bolesław Wallek-Walewski i jego twórczość religijna na chór mieszany, „Pro Musica Sacra" 2014, t. 12, s. 119-129.

${ }^{6}$ Są to m.in. hasła: J. Prosnaka (Stownik muzyków polskich, t. 2, red. J. M. Chomiński, Kraków 1967, s. 266-267), M. Janickiej-Słysz (Kompozytorzy polscy 1918-2000, t. 2: Biogramy, red. M. Podhajski, Gdańsk - Warszawa 2005, s. 1055-1057), J. Miklaszewskiej (Encyklopedia Muzyczna PWM. Część biograficzna, t. 12, red. E. Dziębowska, Kraków 2012, s. 58-59), Z. Lissy (Die Musik in Geschichte und Gegenwart, t. 14, red. F. Blume, Kassel - Bazylea 1968, szp. 168-169 oraz Muzykalnaja Encikłopiedija, t. 1, red. J. Kiełdysz, Moskwa 1973, s. 653), M. Hanuszewskiej (The New Grove Dictionary of Music and Musicians, wyd. 2, t. 27, red. S. Sadie, Londyn 2001, s. 38).

${ }^{7}$ Sesja „Ku uczczeniu pamięci Bolesława Wallek-Walewskiego w 30-tą rocznicę śmierci” odbyła się w PWSM w Krakowie 9 listopada 1974 roku.

${ }^{8}$ Od 1909 roku Teatr im. Juliusza Słowackiego.

${ }^{9}$ Świerczek, op. cit., s. 13.

${ }^{10} \mathrm{Ibid}$. 
Bolesław Juliusz Wallek Walewski urodził się 23 stycznia 1885 roku we Lwowie. Zarówno atmosfera panująca w domu, jak i bogate życie muzyczne i teatralne rodzinnego miasta stwarzały sprzyjające warunki dla ukształtowania się osobowości przyszłego kompozytora. Był artystą wszechstronnie wykształconym, uzdolnionym nie tylko muzycznie, ale także literacko - napisał libretta do dwóch swoich oper: Dola i Pomsta Jontkowa. Studiował w konserwatorium w Krakowie harmonię i kontrapunkt u Władysława Żeleńskiego, grę na fortepianie u Wiktora Barabasza ${ }^{11}$ oraz śpiew u Juliusza Marso, literaturę polską na Wydziale Filozoficznym Uniwersytetu Jagiellońskiego oraz muzykologię na uniwersytecie w Lipsku u Hugo Riemanna i Artura Prüfera.

Wallek Walewski był założycielem i - w latach 1915-1917 oraz 1919-1938 kierownikiem artystycznym Krakowskiego Towarzystwa Operowego (działającego w latach 1914-1938, z przerwą w latach 1924-1930), w którym prowadził wiele przedstawień operowych. Odegrał ważną rolę jako dyrygent propagujący muzykę operową Stanisława Moniuszki, jednego ze swych ulubionych kompozytorów $^{12}$. Kierując operą krakowską, wystawił tam trzy jego opery: Halkę, Verbum nobile i Straszny dwór. Pierwszą z nich była „entuzjastycznie przyjęta” - jak pisze Leon Świerczek - Halka, wystawiona w 1915 roku. Przedstawienie Halki poprowadził Walewski także w Teatrze Wielkim w Poznaniu, w dniu 21 kwietnia 1924 roku. W latach 1917-1919 był dyrygentem w Teatrze Wielkim w Warszawie. Pobyt kompozytora w stolicy był jednak krótkotrwały; w 1919 roku artysta powrócił do Krakowa, by objąć stanowisko dyrektora Towarzystwa Muzycznego. W latach 1919-1938 sprawował funkcję kierownika artystycznego Krakowskiego Towarzystwa Śpiewaczego „Echo”. Od 1910 do 1917 roku był profesorem w Konserwatorium Towarzystwa Muzycznego w Krakowie, w latach 1930-1934

${ }^{11}$ Wiktor Barabasz (1855-1928), pianista, dyrygent i pedagog, założyciel Chóru Akademickiego Uniwersytetu Jagiellońskiego. Był dyrektorem artystycznym Towarzystwa Muzycznego w Krakowie (w latach 1886-1909 i 1918-1921) oraz dyrektorem Konserwatorium Towarzystwa Muzycznego w Krakowie (1921-1928). Zob.: J. Reiss, Barabasz Wiktor, [w:] Polski Stownik Biograficzny, t. 1, red. W. Konopczyński, Kraków 1935, s. 269; M. Negrey, Barabasz Wiktor, [w:] Encyklopedia Muzyczna PWM. Część biograficzna, suplement do t. 1, red. E. Dziębowska, Kraków 1998, s. 32-33; idem, Wiktor Barabasz 1921-28, https://www.amuz.krakow.pl/poczet-rektorow/rektorzy-akademii-muzycznej/wiktor-barabasz/ [data dostępu: 26.09.2017].

${ }^{12} \mathrm{O}$ fascynacji Bolesława Wallek Walewskiego operą, a szczególnie muzyką Stanisława Moniuszki, następująco pisał Józef Reiss: „Obok chóru najbliższą sferą upodobań była dla Walewskiego opera; niemal wszystkie dzieła repertuaru operowego znał on na wylot i do wszystkich arii operowych wykonywanych na estradzie koncertowej akompaniował - z pamięci! Ukochaniem jego był Moniuszko, zwłaszcza «Halka» i «Straszny dwór», a obok tego Gounod i weryści włoscy z Puccinim na czele", J. W. Reiss, Bolestaw Wallek-Walewski. Urodzony w 1885 roku-umart w 1944 roku. Szkic twórczości do roku 1920, „Życie Śpiewacze” 1949, nr 4, s. 34. 
prowadził tam klasę kompozycji, w roku akademickim 1938/39 był dyrektorem tej instytucji. Zmarł 9 kwietnia 1944 roku w Krakowie.

We wszechstronnym dorobku kompozytorskim Walewskiego ważne miejsce zajmują napisane przezeń opery. Były to: opera romantyczna Twardowski (Legenda) do libretta Aleksandra Bandrowskiego ${ }^{13}$, Dola, opera komiczna Żona dwóch mężów do libretta Jerzego Guranowskiego ${ }^{14}$ oraz Pomsta Jontkowa. Jednoaktowa opera Kurhanek Maryli według Adama Mickiewicza pozostała nieukończona. Napisał ponadto dwa obrazy sceniczne: Legenda o Wandzie, Krakusie i smoku (Legenda wawelska) oraz Wesele ślaskie. Wśród oper Wallek Walewskiego największym powodzeniem cieszyła się Pomsta Jontkowa, której libretto stanowiło kontynuację Halki Stanisława Moniuszki. Twórczość Moniuszki była niewątpliwie ważnym źródłem inspiracji dla krakowskiego kompozytora. Preferowanie muzyki wokalnej, znakomite operowanie zespołem chóralnym w utworach wokalnych oraz liczne stworzone przezeń pieśni solowe mogą pośrednio świadczyć także o inspiracji muzyką twórcy Litanii Ostrobramskich.

Genezę powstania opery Pomsta Jontkowa wyznaczają wakacyjne pobyty Bolesława Wallek Walewskiego w Olczy pod Zakopanem, gdzie zetknął się z folklorem, muzyką oraz gwarą podhalańską. Leon Świerczek, wspominając o letnich wyjazdach Walewskiego do domów Księży Misjonarzy w Krzeszowicach, Wilnie i Olczy, pisze, iż

„Najchętniej przebywał w Olczy, gdzie z okien willi napawał się pięknem Tatr, gdzie wsłuchiwał się w poświsty wiatru halnego lub przeżywał

\footnotetext{
${ }^{13}$ Aleksander Bandrowski-Sas (1860-1913), polski śpiewak (tenor), znakomity odtwórca partii w operach i dramatach muzycznych Wagnera. Występował w wielu europejskich teatrach operowych, m.in. w Mediolanie, Londynie, Wiedniu, Berlinie i Frankfurcie nad Menem oraz na scenach polskich (m.in. w Warszawie i Lwowie). Wykonawca tytułowej roli w prapremierze Manru Ignacego Jana Paderewskiego w Dreźnie w 1901 roku, a w rok później na scenie Metropolitan Opera. Autor librett oper Stara baśń Władysława Żeleńskiego i Bolesław Śmialy Ludomira Różyckiego oraz polskiego thumaczenia libretta Śpiewaków norymberskich Richarda Wagnera. Zob.: Z. Jachimecki, Bandrowski Aleksander, [w:] Polski Stownik Biograficzny, t. 1, red. W. Konopczyński, Kraków 1935, s. 256; J. Kański, Bandrowski-Sas Aleksander, [w:] Encyklopedia Muzyczna PWM. Czesść biograficzna, t. 1, red. E. Dziębowska, Kraków 1979, s. 184.

${ }^{14}$ Jerzy Guranowski (1884-1943), literat, satyryk i krytyk. Współpracował m.in. z czasopismami: „Świat”, „Echo Literacko-Artystyczne”, „Kurier Poranny” „Kurier Warszawski”, „Ilustrowany Przegląd Teatralny”, „Przegląd Teatralny i Kinematograficzny”, „Rytm”, „Oko”, „X Muza”, „Wiadomości Filmowe” oraz z pismami satyryczno-politycznymi „Mucha” i „Szczutek”. Opublikował w Warszawie dwie serie Poezji (1912 i 1913), był także autorem tekstów pieśni polskich kompozytorów. Opera Walewskiego Żona dwóch mężów była wstawką do III aktu jego komedii Za króla Sasa, wystawionej w 1920 roku w Teatrze J. Słowackiego w Krakowie. Zob.: Z. Muszyńska, Guranowski Jerzy, [w:] Polski Stownik Biograficzny, t. 9, red. K. Lepszy, Kraków 1960-1961, s. 159-160.
} 
burze górskie. Tu zrodził się pomysł napisania «Pomsty Jontkowej», jako uzupełnienie moniuszkowskiej «Halki». Przez bezpośrednie zaś obcowanie z góralami, poznał ich życie, muzykę i śpiew, odtwarzany później w licznych kompozycjach"15.

Obok muzyki Stanisława Moniuszki, ludowa muzyka i folklor Podhala stały się więc drugim ważnym źródłem inspiracji do napisania tego dzieła. Zarówno muzyka opery, nawiązująca do góralskich przyśpiewek, wykorzystująca skalę góralską, jak i libretto, napisane gwarą podhalańską, zdradzają fascynację kompozytora barwnym światem góralszczyzny. Świadczą o tym również napisane przez niego utwory wokalne do tekstów poetów polskich - piewców piękna tatrzańskiego krajobrazu. Wśród nich wymienić można np. dwa utwory do słów Jana Kasprowicza: Kierdele na chór męski i alt, Na gęśliczkach na chór męski i skrzypce oraz Jak Jasiek Mosiężny... Balladę góralska na chór mieszany i skrzypce do słów Kazimierza Przerwy-Tetmajera. Wśród licznych dokonanych przez kompozytora opracowań odnajdujemy m.in. Suite pieśni góralskich na chór męski, Suite pieśni góralskich z Podhala na 6 głosów oraz Suitę pieśni góralskich na 1 głos, fortepian i skrzypce. Niedokończona pozostała Uwertura góralska na orkiestrę symfoniczną. Walewski zatem swą twórczością, w tym także ukończoną w 1924 roku operą, wpisał się w okres niesłabnącego zainteresowania polskich artystów pięknem Tatr oraz folklorem Podhala, datującego się od czasów Młodej Polski.

Wallek Walewski silnie powiązał libretto Pomsty Jontkowej ze środowiskiem góralskim poprzez wprowadzenie jako jednej z postaci bohatera podań ludowych, Janosika. W operze występują postaci znane z Moniuszkowskiej Halki: Jontek jako stary góral, syn Janusza i Halki, który pojawia się jako postać dorosła, utożsamiona przez Walewskiego z Janosikiem, hersztem zbójników, oraz Pani Zofja, wdowa po Januszu z Odrowąża. Nowymi zaś osobami są: góralka Jagusia, córka Zofii i Janusza - Helena, Starosta oraz jego syn Wacław, a ponadto wprowadzone są postaci Księdza oraz Młodego i Starego Górala.

Akcja Pomsty Jontkowej koncentruje się wokół zemsty, której pragnie dokonać Jontek na bogaczach i możnych panach za doznane przezeń w młodości krzywdy. Wychowuje on syna Halki i Janusza, Janosika, na zbójnika, rabującego mienie bogatych i oddającego je biednym. Helena zakochana jest w starościcu Wacławie, który porywa ją z domu rodzinnego. Błądzą oni w górach, gdy napotyka ich na hali Jontek. Wówczas to postanawia on doprowadzić do ślubu Janosika z Heleną - jego przyrodnią siostrą, aby imię Janusza - ojca obydwojga rodzeństwa - okryło się hańbą. Janosik pragnie uwięzić starościca, jednak

${ }^{15}$ L. Świerczek, Bolesław Wallek-Walewski (ur. 23. I. 1885 r. we Lwowie - zm. 9. IV. 1944 r. w Krakowie), „Poradnik Muzyczny” 1949, nr 2, s. 4. 
wskutek kłótni między góralami szlachcic zostaje zabity, Helenę zaś herszt zbójników zatrzymuje pod strażą. Janosik postanawia ożenić się z Heleną, szykuje już góralskie wesele, które jednak nie dochodzi do skutku. Widząc smutek Heleny, rozgniewany odprawia wszystkich gości weselnych. W Akcie III zakochana w zbójniku Jagusia wydaje żandarmom Janosika, zostaje on oskarżony o morderstwo i uwiedzenie. Ostatni, IV akt ukazuje Janosika, którego starosta skazał na dożywotnie więzienie, przebywającego w więziennej celi. Przybywa tam Helena, która od swej matki dowiedziała się, czyim synem jest Janosik i odkrywa przed nim prawdę. Przekupiła straże i pragnie oswobodzić swego brata. Akcja komplikuje się jednak, gdyż pojawia się Jontek na czele grupy górali, którzy chcą uwolnić Janosika siłą. W zamieszaniu Janosik ginie, zastrzelony z karabinu, Jontek zaś popada $\mathrm{w}$ obłęd.

Halka oraz Pomsta Jontkowa stanowiły i uważane były przez współczesnych za cykl, chociaż dzieła te nie zostały napisane przez tego samego kompozytora, jak np. w przypadku Wagnerowskiej tetralogii Pierścień Nibelunga. Podkreślić należy, iż obydwie opery wykonywane były razem w ramach przedstawien „Opery Górskiej” w Zakopanem. Zygmunt Latoszewski pisał w 1926 roku przed poznańską premierą opery Walewskiego, iż

„[...] temat opery, jej akcja, pomyślana jako dalszy ciąg, a raczej uzupełnienie akcji tragicznej «Halki», obiecują wiele oryginalnego i są istotnie w dziejach opery polskiej czemś wyjątkowem"16.

Wskazał, iż w sytuacji, gdy w muzyce współczesnej następują ciągłe zmiany poglądów estetycznych i odwrót od romantyzmu,

„[...] zbliżenie [...] ideowe do nastrojów «Halki» było wobec tak gruntownie zmienionego języka muzycznego poczynaniem śmiałem i niezwykle trudnem"17.

W obydwu operach istnieją elementy wspólne, łączące je w koherentną artystycznie całość. Zarówno Halka (w wersji warszawskiej), jak i Pomsta Jontkowa, to opery czteroaktowe, w ich librettach wprowadzane są te same postaci - Jontka i Zofii, w obydwu operach ważne znaczenie mają konflikty społeczne między warstwą szlachty a chłopstwem, obydwie mają tragiczne, smutne zakończenie. Wallek Walewski podobnie jak Moniuszko w Halce określa w partyturze miejsce

${ }^{16}$ Z. Latoszewski, Wstęp, [w:] Pomsta Jontkowa, napisał Bolesław Wallek-Walewski, Przewodnik Operowy „PARa”, Poznań 1926, Nakład Biura Ogłoszeń „PAR” w Poznaniu, s. 8.

${ }^{17}$ Ibid., s. 9. 
i czas akcji Pomsty Jontkowej, używając sformułowania: „Rzecz dzieje się [...]”. Akcja pierwszych dwóch aktów Halki toczy się przed zamkiem Stolnika w okolicy Krakowa, kolejnych zaś dwóch - w wiosce należącej do Janusza, w górach. Akcja Pomsty Jontkowej rozgrywa się na Podhalu, w górach, oraz w Odrowążu (wsi położonej niedaleko Nowego Targu, rodzinnej miejscowości Janusza). Historia opisana w Pomście toczy się w pierwszych dziesiątkach XIX stulecia, w Halce mowa jest o wydarzeniach mających miejsce u schyłku XVIII wieku. O muzycznych związkach pomiędzy obu operami świadczy wprowadzenie przez Walewskiego motywów przewodnich. Moniuszko stosuje w swojej operze motywy przypominające, które mogą pojawić się już w uwerturze i powracają później w toku muzycznym opery (np. motyw Halki czy motyw arii Jontka). Zarówno w Halce, jak i w Pomście Jontkowej pojawiają się tańce góralskie, przy czym w operze Walewskiego mają one charakter dziecięcej pantomimy baletowej („tańce małych góralików"18). Na bezpośredni związek z Halka wskazują zaś wprowadzone przez Wallek Walewskiego cytaty motywów z tej opery.

Jeden z motywów pojawiający się w I Akcie opery Pomsta Jontkowa jest zaczerpnięty z początkowej melodii środkowej części arii Jontka z IV Aktu opery Halka „Szumią jodły na gór szczycie”. Wallek Walewski nie tylko cytuje ten motyw, ale także wprowadza (w wersji przekształconej) całe zdanie muzyczne z Moniuszkowskiej arii, przedstawiając je w dwóch różnych ujęciach kolorystycznych. Opracowanie tego fragmentu przez Moniuszkę eksponuje przede wszystkim śpiewną melodię, poprzez zdwojenie głosu wokalnego przez skrzypce I oraz częściowo także przez instrumenty dęte. W akompaniamencie, który podporządkowany jest linii wokalnej, dominuje faktura homofoniczna. Wallek Walewski interpretuje tę melodię odmiennie. Pojawia się ona początkowo w partii 2 obojów i opracowana jest kontrapunktycznie, z użyciem imitacji. Jest dodatkowo wyeksponowana poprzez zaznaczoną przy niej dynamikę forte, na tle smyczków grających dyskretny akompaniament $\mathrm{w}$ dynamice pianissimo, dobarwionych cichym brzmieniem kotłów. Następnie melodię podejmują skrzypce I i II, również prezentując ją w opracowaniu polifonicznym, stanowiącym akompaniament dla śpiewu Jontka. Partia wokalna w tym fragmencie - poprzez zastosowanie analogicznego rytmu - również nawiązuje do motywu z Halki.

Podstawową różnicę stylistyczną między obydwoma operami wyznaczają natomiast trzy elementy: warstwa językowa librett, główne założenia dramaturgiczne oraz styl muzyczny, wynikający z odmiennych założeń stylistycznych przyjętych przez obydwu kompozytorów. Libretto Halki napisane zostało przez

${ }^{18}$ B. Wallek Walewski, Pomsta Jontkowa, autograf, Biblioteka Jagiellońska, sygn. Muz. Rkp 2012 D 53/16/110. 
Pobrane z czasopisma Annales L - Artes http://artes.annales.umcs.pl

Data: 26/04/2023 10:20:39

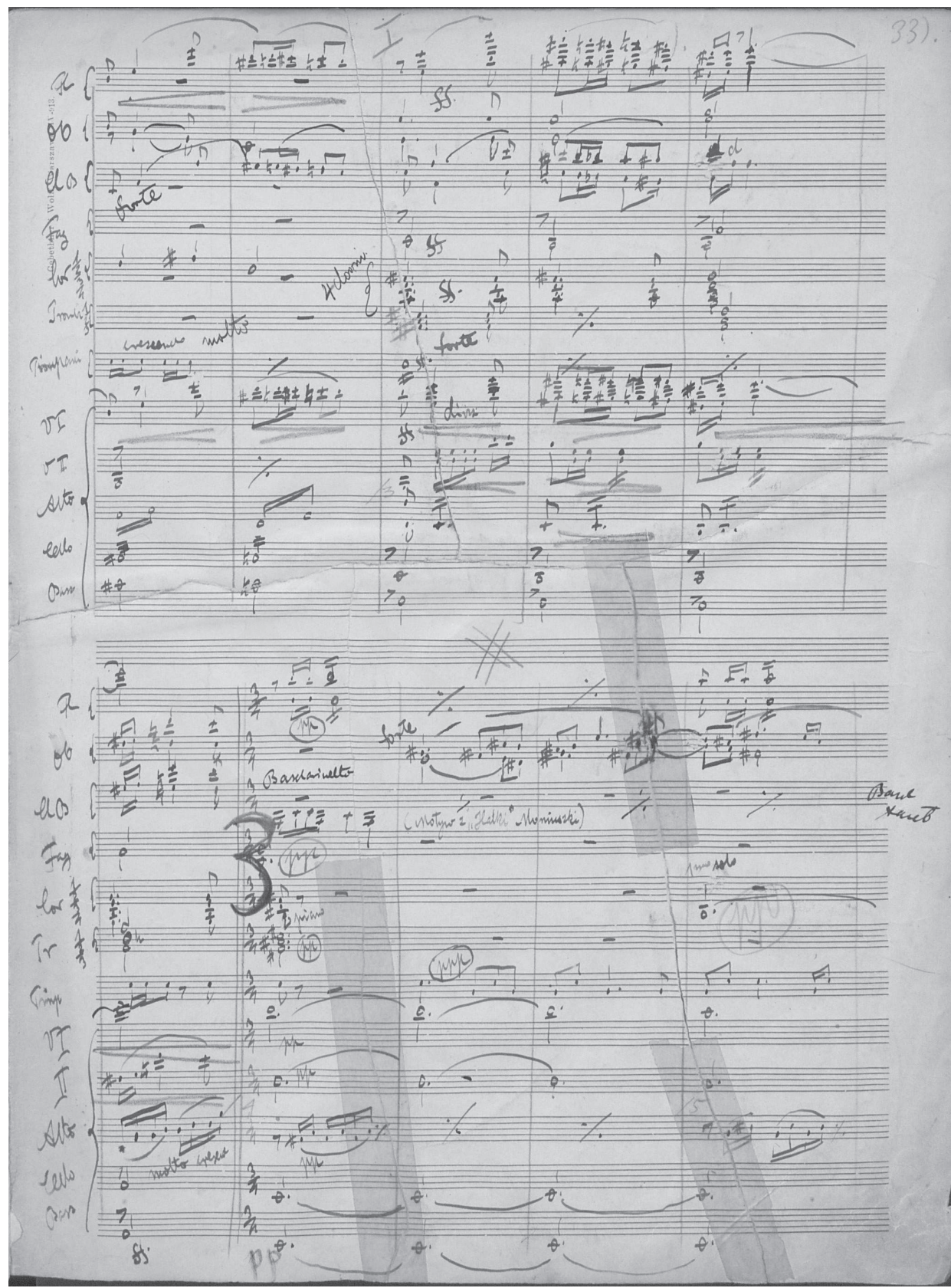

Ilustracja 1. Motyw z Halki Stanisława Moniuszki i jego opracowanie w Akcie I Pomsty Jontkowej Bolesława Wallek Walewskiego. Autograf, Biblioteka Jagiellońska, sygn. Muz. Rkp 2012 D 53/16/110; cd. na s. 67. 
Pobrane z czasopisma Annales L - Artes http://artes.annales.umcs.pl

Data: 26/04/2023 10:20:39

Inspiracje Moniuszkowskie w muzyce XX wieku. Opera Pomsta Jontkowa...

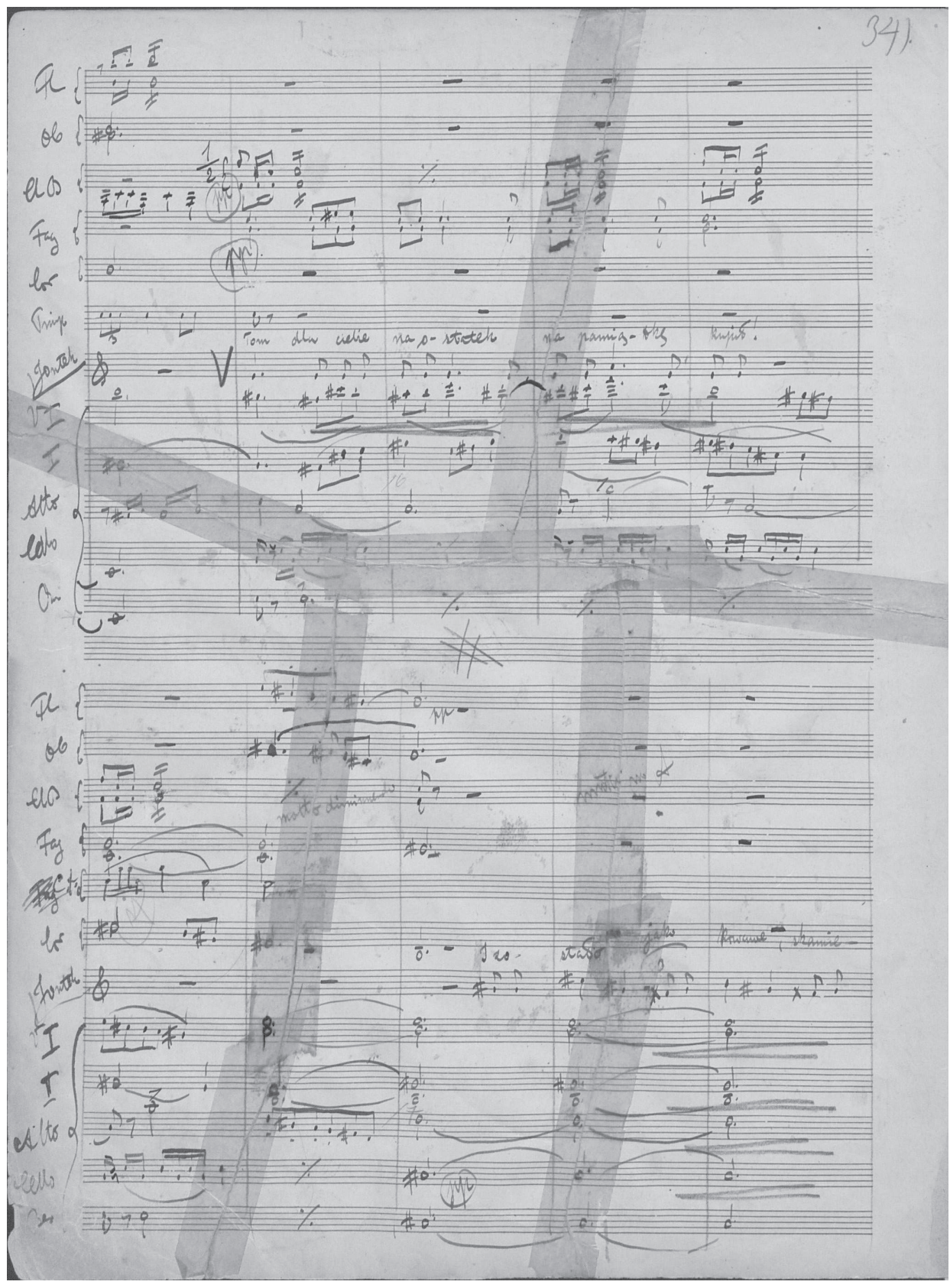


Włodzimierza Wolskiego bez aluzji do elementów gwarowych, natomiast Bolesław Wallek Walewski wykorzystał w szerokim zakresie gwarę podhalańską, którą posługują się występujące $\mathrm{w}$ operze postaci górali. W przeciwieństwie do Halki, w której interpretacjach bądź podkreślany jest dramat osobisty głównej bohaterki, bądź zawarte w operze konflikty społeczne, osią dramatu Wallek Walewskiego jest motyw zemsty górala na możnych panach. Był to ważny wątek w polskiej świadomości społecznej i kulturowej od czasu tragicznych wydarzeń, które miały miejsce podczas rzezi galicyjskiej w 1846 roku. Postać Jakuba Szeli, pojawiająca się w dramacie Wesele Stanisława Wyspiańskiego (jako Upiór - jedna z postaci fantastycznych), być może mogła przypomnieć ten wątek kompozytorowi. Wallek Walewski, który był z wykształcenia także polonistą, prawdopodobnie mógł znać sztukę Włodzimierza Wolskiego Ojciec Hilary, w której pojawia się temat zemsty chłopa za doznane od szlachciców krzywdy. Pierwowzór libretta Halki, sztuka pod tytułem Halszka Włodzimierza Wolskiego, również wykorzystuje motyw zemsty, jednak w dziele tym dokonuje jej szlachcic Janusz, który zabijając własną matkę mści się za nakazane przez nią zabójstwo chłopki Halszki.

Styl muzyczny opery Pomsta Jontkowa Wallek Walewskiego wykazuje $\mathrm{z}$ jednej strony pokrewieństwo z muzyką Wagnera ${ }^{19}$, z drugiej zaś - z nurtem muzycznego folkloryzmu. Walewski stosuje w swej operze powiększony skład orkiestry symfonicznej. Zbliżając się do założeń przyjętych przez Wagnera w Lohengrinie, wprowadza potrójną obsadę instrumentów dętych drewnianych i blaszanych (z poczwórną obsadą rogów), podczas gdy w Halce przeważnie wykorzystywana jest podwójna obsada tych instrumentów (oprócz poczwórnej obsady rogów i potrójnej puzonów). Zastosowany przez Moniuszkę skład perkusji: kotły, triangel, wielki bęben, talerze, powiększa Walewski jeszcze o werbel. W Pomście Jontkowej kompozytor, nawiązując do wzorców Wagnerowskich, wprowadza motywy przewodnie. Są to motywy Jontka, Janosika, Heleny, Starosty, Pani Zofii, Wacława, Jagusi oraz motyw przeczucia śmierci Janosika. Charakterystyczny jest rozpoczęty dwoma wznoszącymi się skokami o interwał kwarty w rytmie synkopowanym motyw Jontka, głęboko zakorzenione zaś w stylistyce ludowej muzyki góralskiej są motywy Janosika i Jagusi, skomponowane w skali góralskiej. W sposobie traktowania lejtmotywów

\footnotetext{
${ }^{19} \mathrm{Na}$ związki muzyki innej opery Wallek Walewskiego, Twardowski. Legenda, z dramatem muzycznym Wagnera wskazuje Marcin Gmys: „Jest to - jak Bolesław Różyckiego - dzieło świadczące o przyswojeniu sobie przez kompozytora pewnych elementów teorii dramatu muzycznego Wagnera (np. Walewski dość skrupulatnie przestrzega zasady niejednoczesnego nakładania na siebie głosów wokalnych)"'. M. Gmys, Harmonie i dysonanse. Muzyka Młodej Polski wobec innych sztuk, Poznań 2012, s. 97.
} 
Walewski również nawiązuje do dramatów Wagnera - motywy te mają istotną rolę w rozwoju materiału muzycznego i ukazywane są przez kompozytora w różnych odcieniach kolorystycznych. Na przykład w orkiestrowym wstępie do I Aktu Pomsty (Andante) pojawia się charakterystyczny motyw Jontka, wprowadzony przez trąbkę solo, który następnie podejmuje flet piccolo, później zaś przekształcony jego początek gra ponownie trąbka; nawiązanie do tego motywu pojawia się potem w partii skrzypiec I i II, i w końcu w partii dwóch fletów, poprzedzając arię Jontka „Hej miły, mocny Boże”, rozpoczętą wspomnianym motywem. Opera Walewskiego, podobnie jak dzieła Wagnera, w warstwie harmonicznej wykorzystuje rozszerzoną tonalność dur-moll, jednak wzbogaconą o elementy folkloru podhalańskiego (skala góralska). Dominują w niej monologi i dialogi głównych bohaterów, mniejsze znaczenie mają partie chóralne. O oryginalności Pomsty Jontkowej decydują przede wszystkim melodyjne partie powierzone głównym bohaterom dzieła. Ich śpiewna melodyka zapewne miała w zamyśle kompozytora powiązać drugą część operowego cyklu z Moniuszkowską Halka, słynącą z pięknych, kantylenowych arii, jak dumka Jontka „Szumią jodły na gór szczycie” z IV Aktu czy aria Halki „Gdyby rannym słonkiem” z II Aktu.

Silne nasycenie warstwy literackiej dzieła folklorem zostało jeszcze wzmocnione przez głębokie osadzenie muzyki Pomsty Jontkowej w muzycznej aurze góralszczyzny. W przeciwieństwie do Halki Moniuszki, gdzie nawiązania w muzyce do góralskiego folkloru pojawiają się sporadycznie, głównie w słynnych Tańcach góralskich, Walewski oparł w dużej mierze styl muzyczny całej opery na nawiązaniu do folkloru podhalańskiego. Stylizowane melodie ludowe są podstawą melodyki w tej operze, wprowadzony jest także cytat góralskiej melodii ludowej: „Ej, idzie se Janicek, ej popod wierchowiny” w chórze górali z aktu II: „Oj zahuciały góry, oj zahuciały lasy”"20. W stylu muzycznym opery Pomsta Jontkowa pojawiają się także tendencje impresjonistyczne. Kompozytor eksploatuje rozmaite odcienie barw dźwiękowych poprzez wykorzystywanie tłumików dla takich instrumentów, jak trąbki, skrzypce i altówki. Stosuje typową dla impresjonizmu grę divisi (np. w partii altówek, wiolonczel i kontrabasów oraz w partii obojów), wprowadza glissando w partii harfy (Akt I, s. 99 autografu $^{21}$ ), podobnie jak Debussy często eksponuje brzmienie instrumentów dętych drewnianych. Zaznaczyć należy także, iż kompozytor szczególnie chętnie posługuje się techniką kontrapunktyczną w partiach instrumentów dętych drewnianych (niekiedy także technika ta używana jest w partiach

\footnotetext{
${ }^{20}$ Quasnik, op. cit., s. 58-59.

${ }^{21}$ Wallek Walewski, op. cit.
} 
granych przez kwintet smyczkowy, np. imitacja swobodna w Akcie II, s. 147 autografu ${ }^{22}$ ). Poprzez łączenie polifonii z fakturą homofoniczną wpisuje się Walewski swą operą w kształtujący się dopiero w Polsce nurt muzycznego neoklasycyzmu ${ }^{23}$.

Zygmunt Latoszewski w recenzji poznańskiego przedstawienia opery chwalił muzykę dzieła, podkreślając śpiewność melodyki oraz nowoczesną instrumentację, krytykując jednak libretto, które jego zdaniem wykazuje brak myśli przewodniej $^{24}$. Leon Świerczek zauważa kontrast stylistyczny zastosowany przez kompozytora, który

„Świat góralski odmalował muzyką i gwarą podhalańską; świat natomiast szlachecki oddał materiałem dźwiękowym bliskim muzyce Pucciniego czy d'Alberta"25.

W tekstach poświęconych Walewskiemu wyrażane były pełne uznania opinie o występujących w operze partiach chóralnych - był on wszak znakomitym kompozytorem muzyki chóralnej. Włodzimierz Poźniak pisał, iż

„Obok niektórych ustępów solowych (np. monolog Janosika w ostatnim akcie) szczególnie udane są partie zespołowe, a zwłaszcza chóralne, w których budowie i traktowaniu kolorystycznym był Walewski największym mistrzem wśród polskich kompozytorów swoich czasów”26.

Pomsta Jontkowa była najbardziej znanym i często wystawianym w Polsce dziełem operowym krakowskiego kompozytora. Jej prapremiera odbyła się w Teatrze Wielkim w Poznaniu 16 października 1926 roku, pod dyrekcją Zygmunta Wojciechowskiego, w reżyserii Gabriela Gorskiego. Dekoracje wykonano według pomysłu Stanisława Jarockiego ${ }^{27}$, który zaprojektował również kostiumy

${ }^{22}$ Ibid.

${ }^{23}$ Zofia Helman pisze, iż „O pojawieniu się neoklasycyzmu w muzyce polskiej można mówić około połowy lat dwudziestych, ale w pierwszej fazie było to raczej kształtowanie się charakterystycznej dla tego kierunku postawy i założeń artystycznych niż ich realizacja w twórczości”, Z. Helman, Neoklasycyzm w muzyce polskiej XX wieku, Kraków 1985, s. 50.

${ }^{24}$ Z. Latoszewski, Poznań. Premiera Wallek-Walewskiego „Pomsty Jontkowej”, „Muzyka” 1926, nr 11-12, s. 612.

${ }^{25}$ Świerczek, Bolesław Wallek Walewski..., s. 30.

${ }^{26}$ W. Poźniak, Bolesław Wallek Walewski, „Ruch Muzyczny” 1959, nr 11, s. 8.

${ }^{27}$ Stanisław Jarocki (1887-1966), scenograf i malarz, autor scenografii do przedstawień teatralnych oraz wystawień oper i baletów w Polsce. Współpracował ze scenami operowymi m.in. w Bytomiu, Wrocławiu i Poznaniu. Zob.: http://www.encyklopediateatru.pl/osoby/11964/stanislaw-ja- 
wykonawców; choreografię opracował Maksymilian Statkiewicz ${ }^{28}$. W rolach głównych wystąpili: Michał Prawdzic ${ }^{29}$ (Jontek), Aleksander Karpacki (Janosik), Stefania Marynowicz-Madejowa (Jagusia), Wanda Roessler-Stokowska (Pani Zofja), Irena Cywińska (Helena), Hugo Zathey (Starosta), Ignacy Wiśniewski (Wacław), Zygmunt Zawrocki (Stary Góral), Aleksander Klichowski (Młody Góral) i Kazimierz Wawrzyniecki (Ksiądz). Jak pisał autor zamieszczonej w „Muzyce” recenzji z premiery poznańskiej:

„Przebieg premjery był wyją̧tkowo uroczysty; obecnemu na przedstawieniu kompozytorowi publiczność zgotowała kilkakrotnie owacje"30.

Na scenie poznańskiej zaprezentowano wielokrotnie przedstawienia Pomsty Jontkowej, wznowiono je w 1929 roku (w rolę Jontka wcielił się wówczas Stanisław Drabik ${ }^{31}$ ). Na przełomie lat dwudziestych i trzydziestych XX wieku opera ta cieszyła się w Polsce dużą popularnością, wystawiły ją także inne teatry operowe w kraju (z wyjątkiem sceny warszawskiej). W Katowicach grano ją 30 czerwca 1927 roku, w styczniu i lutym 1928 roku, ponadto opera katowicka wystąpiła również z przedstawieniami w Krakowie 3, 7 i 9 lipca 1927 roku. We Lwowie operę Walewskiego grano kilkanaście razy (premiera miała miejsce 31 marca

rocki [data dostępu: 30.09.2017]; http://filmpolski.pl/fp/index.php?osoba=1112316 [data dostępu: 2.10.2017].

${ }^{28}$ Maksymilian Statkiewicz (1889-1976), tancerz, choreograf i pedagog. Występował m.in. w Baletach Rosyjskich Sergiusza Diagilewa. Był solistą, choreografem i baletmistrzem w Teatrze Wielkim w Poznaniu. Autor choreografii do polskiej prapremiery Harnasiów Karola Szymanowskiego (1938). Zob.: J. Pudełek, Statkiewicz Maksymilian, [w:] Polski Stownik Biograficzny, t. 42, red. A. Romanowski, Kraków 2003-2004, s. 570-572, eadem, Statkiewicz Maksymilian, [w:] Encyklopedia Muzyczna PWM. Część biograficzna, t. 10, red. E. Dziębowska, Kraków 2007, s. 86.

${ }^{29}$ Michał Prawdzic (1881-1959), pseudonimy: Leyman, Layman, Lajman, śpiewak (tenor) i pedagog, uczył się m.in. u Jana Reszke, występował w operach w Warszawie, Wilnie, Krakowie, Lwowie, Poznaniu i Wiedniu. W 1927 roku występował za granicą (m.in. w Paryżu, Rzymie, Mediolanie, Wenecji, Florencji i Pradze). Był profesorem śpiewu w Instytucie Muzycznym w Nicei (1929-1939), w latach powojennych zaś w Szkole Muzycznej w Toruniu i w Szczecinie. Zob.: J. Grabowski, Prawdzic Michat, [w:] Polski Stownik Biograficzny, t. 28, red. E. Rostworowski, Kraków 1984-1985, s. 361-362; http://www.encyklopediateatru.pl/osoby/41769/michal-prawdzic-layman [data dostępu: 2.10.2017].

${ }^{30}$ Latoszewski, Poznań. Premiera Wallek-Walewskiego..., s. 612.

${ }^{31}$ Stanisław Drabik (1900-1971), śpiewak (tenor) i reżyser operowy, w latach 1931-1939 pierwszy tenor opery w Belgradzie, występował na polskich i zagranicznych scenach operowych; w latach 1945-1947 dyrektor, a w 1951-1952 kierownik artystyczny Państwowej Opery we Wrocławiu. Zob.: L. Markiewicz, Drabik Stanisław, [w:] Encyklopedia Muzyczna PWM. Część biograficzna, t. 2, red. E. Dziębowska, Kraków 1984, s. 444; http://www.e-teatr.pl/pl/osoby/14203.html [data dostępu: 2.10.2017]. 
Pobrane z czasopisma Annales L - Artes http://artes.annales.umcs.pl

Data: 26/04/2023 10:20:39

Joanna Miklaszewska

1928 roku $^{32}$ ). Krakowska premiera Pomsty Jontkowej w reżyserii Stefana Romanowskiego, pod dyrekcją kompozytora, odbyła się 8 lutego 1932 roku w Teatrze im. Słowackiego. Wspomnieć należy także, iż poetka Maria Paruszewska ${ }^{33}$ czyniła starania o wystawienie dzieła Walewskiego w Ameryce; wystawienie to ostatecznie nie doszło do skutku ${ }^{34}$.

W sierpniu 1931 roku Krakowskie Towarzystwo Operowe zaprezentowało po raz pierwszy przedstawienia Pomsty Jontkowej w Zakopanem, wówczas ważnym centrum kulturalnym, skupiającym i przyciągającym najwybitniejszych artystów - poetów i malarzy zafascynowanych tatrzańskim krajobrazem, reżyserów i aktorów, kompozytorów i słynnych wykonawców, obfitującym w rozmaite wydarzenia artystyczne. Mieszkali w stolicy Tatr Karol Szymanowski oraz - do swej śmierci w 1926 roku - Jan Kasprowicz, działały tam i występowały gościnnie rozmaite teatry, w latach dwudziestych swoje sztuki wystawiał Stanisław Ignacy Witkiewicz, duże znaczenie dla ówczesnego życia muzycznego miała działająca tam kapela Obrochtów. W latach 1930-1931 odbyło się wiele różnych imprez artystycznych na znakomitym poziomie - m.in. wystawiał przedstawienia teatr „Reduta” Juliusza Osterwy oraz teatr „Ateneum" Stefana Jaracza, występowała Irena Solska, koncertowali pianiści Egon Petri i Zbigniew Drzewiecki, bawili zakopiańską publiczność Hanka Ordonówna oraz Zula Pogorzelska z Konradem Tomem. Odbywały się także przedstawienia wystawiane przez artystów-amatorów, m.in. 31 maja 1931 roku artyści z Nowego Targu zaprezentowali sztukę Adolfa Walewskiego Ach, to Zakopa$n e^{35}$. Wśród innych ważnych wydarzeń tego okresu w stolicy Tatr wspomnieć należy uroczyste przeniesienie zwłok Władysława Orkana, wielkiego piewcy Podhala, w pierwszą rocznicę jego śmierci do Zakopanego, w dniu 16 maja 1931 roku (kilka miesięcy wcześniej rozpoczęto prace nad założeniem ulicy Władysława Orkana w Zakopanem). Tytuł obywatela honorowego Zakopanego otrzymali w 1931 roku Kornel Makuszyński i Marian Dąbrowski.

32 Źródło: Almanach Lwowski „,Ateneum” 1928, www.lwow.home.pl/almanach/teatry1928.html [data dostępu: 20.09.2013].

${ }^{33}$ Maria Paruszewska (1864-1937), literatka, prowadziła w Poznaniu salon literacko-muzyczny, który odwiedzali m.in. Feliks Nowowiejski, Raul Koczalski, Ludomir Różycki, Ignacy Friedman, Henryk Melcer, Ada Sari, Olga Boznańska i Bolesław Wallek Walewski. Autorka zamieszczanych w prasie wielu sprawozdań z oper i koncertów oraz wierszy (opublikowała kilka tomików poezji). Zob.: S. Wróbel, Paruszewska z Kramarkiewiczów Maria, [w:] Polski Słownik Biograficzny, t. 25, red. E. Rostworowski, Kraków 1980, s. 221-222.

${ }^{34}$ Wspomina o tym Świerczek, Bolesław Wallek Walewski..., s. 30.

${ }^{35}$ Informacje podane [za:] K. Kwaśniewski, Kronika zakopiańska (w dziale Podhale i Zakopane), „Wierchy” 1931, t. 9, s. 188. 
Jednym z najważniejszych wydarzeń artystycznych 1931 roku były - określone przez krytykę jako rewelacja sezonu ${ }^{36}$ - przedstawienia inaugurujące tzw. „Operę Górską" na wolnym powietrzu, podczas których wykonano kilkakrotnie w sierpniu cykl 2 oper, złożony z Halki Moniuszki oraz Pomsty Jontkowej Bolesława Wallek Walewskiego. Zostały one zorganizowane przez zarząd uzdrowiska, z inicjatywy majora Juliusza Schreyera ${ }^{37}$, kapelmistrza 20. Pułku Piechoty Ziemi Krakowskiej, który dyrygował przedstawieniami Halki (Pomstę Jontko$w a$ poprowadził zza pulpitu dyrygenckiego sam kompozytor). Przedstawienia, z udziałem zespołu Krakowskiego Towarzystwa Operowego, miały miejsce na małym stadionie Komitetu Imprez Sportowych na Równi Krupowej. Scenografia zaprojektowana przez Mieczysława Różańskiego ${ }^{38}$ i Kazimierza Chmurskiego ${ }^{39}$ znakomicie współgrała $\mathrm{z}$ naturalną scenerią widocznych w tle lasów oraz pasma Tatr. Scena została ponadto sztucznie zalesiona. Przedstawienia podziwiała publiczność licząca kilka tysięcy słuchaczy, zostały one znakomicie przyjęte przez polską prasę. Recenzent czasopisma „Śpiewak”, Władysław Fabry, pisał:

„Folklor tatrzański reprezentowała prawdziwa muzyka góralska, przy wtórze której tańczyli autentyczni górale, goście weselni wjeżdżali na prawdziwych «przedwojennych» furkach góralskich, a przy końcu przedstawienia hulał najudatniejszy wiatr halny, który omal nie powyrywał plastycznych dekoracyj, wybudowanych z drzewa. Halka z łuczywem w ręku

\footnotetext{
${ }^{36}$ Karol Kwaśniewski pisał, iż: „Rewelacją jednak ubiegłego sezonu były przedstawienia «Opery Górskiej» na wolnem powietrzu [...]”, ibid., s. 188.

${ }^{37}$ Juliusz Schreyer (1883-1957), kompozytor i dyrygent, major Wojska Polskiego, dyplomowany kapelmistrz. Pisał muzykę symfoniczną, wokalno-instrumentalną oraz sceniczną (m.in. operetki). Zob.: http://www.encyklopediateatru.pl/osoby/81081/juliusz-schreyer [data dostępu: 30.09.2017]; http://www.bibliotekapiosenki.pl/osoby/Schreyer_Juliusz_Ludwik/biografia [data dostępu: 30.09.2017]; Kwaśniewski, op. cit., s. 188.

${ }^{38}$ Mieczysław Marian Różański (1903-1969), scenograf. Współpracował m.in. z Teatrem Miejskim i Teatrem Wielkim we Lwowie, Teatrem im. J. Słowackiego w Krakowie, Teatrem Polskim w Katowicach i teatrami w Warszawie. Zob.: M. Nowak, Różański Mieczysław Marian, [w:] Polski Slownik Biograficzny, t. 32, red. E. Rostworowski, Kraków 1989-1991, s. 503-504; http://www.encyklopediateatru.pl/osoby/38496/mieczyslaw-rozanski [data dostępu: 2.10.2017].

${ }^{39}$ Kazimierz Chmurski (1897-1942), malarz. Walczył w I oraz II wojnie światowej. W 1924 roku wyjechał do Paryża i otworzył tam pracownię malarską. Później był związany ze środowiskiem artystycznym Krakowa, należał do Grupy Dziesięciu. Malował m.in. portrety i pejzaże. Zmarł w obozie koncentracyjnym w Oświęcimiu. Zob.: S. Bołdok, H. Kotkowska, Chmurski Kazimierz, [w:] Stownik artystów polskich i obcych w Polsce działających: malarze, rzeźbiarze, graficy, t. 1, red. J. Maurin Białostocka i in., Wrocław 1971, s. 325-326.
} 
robiła przy akompaniamencie jego dzikich pogwizdów wrażenie naprawdę wstrząsające i niezapomniane"

Po II wojnie światowej operę Pomsta Jontkowa wystawiła Opera Wrocławska, w inscenizacji i reżyserii Zygmunta Bilińskiego ${ }^{41}$, pod kierownictwem muzycznym Adama Kopycińskiego ${ }^{42}$. Autorką scenografii była Irena Lorentowicz, choreografii zaś - Mikołaj Kopiński. Premiera odbyła się 23 listopada 1970 roku. Wykonawcami głównych ról w przedstawieniach Pomsty Jontkowej w Operze Wrocławskiej byli: Alfred Czopek, Adam Dachtera i Józef Widera (Jontek), Bernard Nowacki, Tadeusz Prochowski i Janusz Temnicki (Janosik), Janina Romańska, Halina Szczegłowska, Wanda Szczepanik i Urszula Walczak (Zofia), Salomea Bilińska, Krystyna Czaplarska i Halina Słoniowska ${ }^{43}$ (Helena), Zygmunt Biliński, Maciej Kański i Henryk Łukaszek (Starosta nowotarski), Edwin Borkowski, Tadeusz Cimaszewski i Feliks Tarnawski (Wacław). Przedstawieniami dyrygowali: Adam Kopyciński, Jan Marynowski i Andrzej Jurkiewicz.

${ }^{40}$ W. Fabry, Halka i Jontek u stóp Giewontu. (Opera górska w Zakopanem.), „Śpiewak” 1931, nr 9, s. 118.

${ }^{41}$ Zygmunt Biliński (1918-1974), śpiewak, reżyser i pedagog. Reżyserował przedstawienia w Operze Wrocławskiej, w latach 1967-74 wykładał w Państwowej Wyższej Szkole Muzycznej we Wrocławiu. Zob.: http://www.encyklopediateatru.pl/osoby/4975/zygmunt-bilinski [data dostępu: 30.09 .2017$]$.

${ }^{42}$ Adam Kopyciński (1907-1982), dyrygent, pianista, kompozytor i pedagog, działał jako dyrygent zespołów chóralnych i orkiestrowych, w latach 1951-1953 oraz 1961-1970 był dyrektorem naczelnym Opery Wrocławskiej, w latach 1957-1963 rektorem PWSM we Wrocławiu. Zob.: M. Zduniak, Kopyciński Adam, [w:] Encyklopedia Muzyczna PWM. Część biograficzna, t. 5, red. E. Dziębowska, Kraków 1997, s. 166-167.

${ }^{43}$ Halina Słoniowska (1930-1991), śpiewaczka (sopran), laureatka I nagrody na Konkursie Śpiewaczym im. S. Moniuszki w Warszawie. Była solistką Opery Wrocławskiej, współpracowała z Operą w Warszawie, występowała także w wielu miastach europejskich. Ceniona przez krytykę jako wybitna interpretatorka partii Halki w operze Moniuszki. Zob.: M. Matuszewska, Portret rodzinny w Operze Wrocławskiej, http://www.gazetawroclawska.pl/artykul/67153,portret-rodzinny-w-operzewroclawskiej,id,t.html [data dostępu: 2.10.2017]; http://www.encyklopediateatru.pl/osoby/56849/ halina-sloniowska [data dostępu: 2.10.2017]; https://archiwum.teatrwielki.pl/baza/-/o/halina-sloniowska/198311/20181 [data dostępu: 2.10.2017]. 
Pobrane z czasopisma Annales L - Artes http://artes.annales.umcs.pl

Data: 26/04/2023 10:20:39

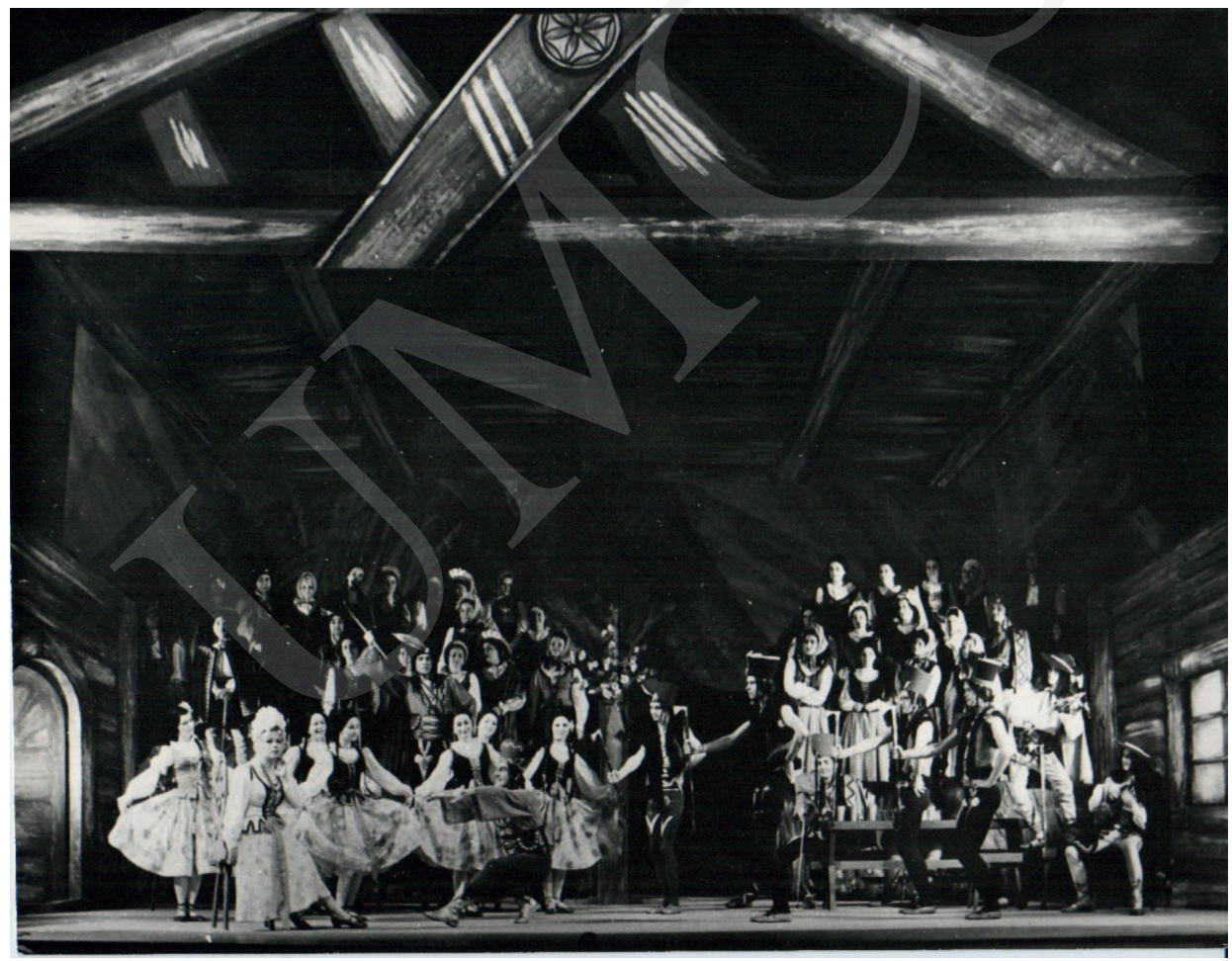

Ilustracja 2. Bolesław Wallek Walewski Pomsta Jontkowa, premiera w Operze Wrocławskiej 23 XI 1970, od lewej: Krystyna Czaplarska (Helena) oraz artyści chóru i baletu Opery Wrocławskiej, Archiwum Opery Wrocławskiej, nr sygn. 108. 
Pobrane z czasopisma Annales L - Artes http://artes.annales.umcs.pl

Data: 26/04/2023 10:20:39

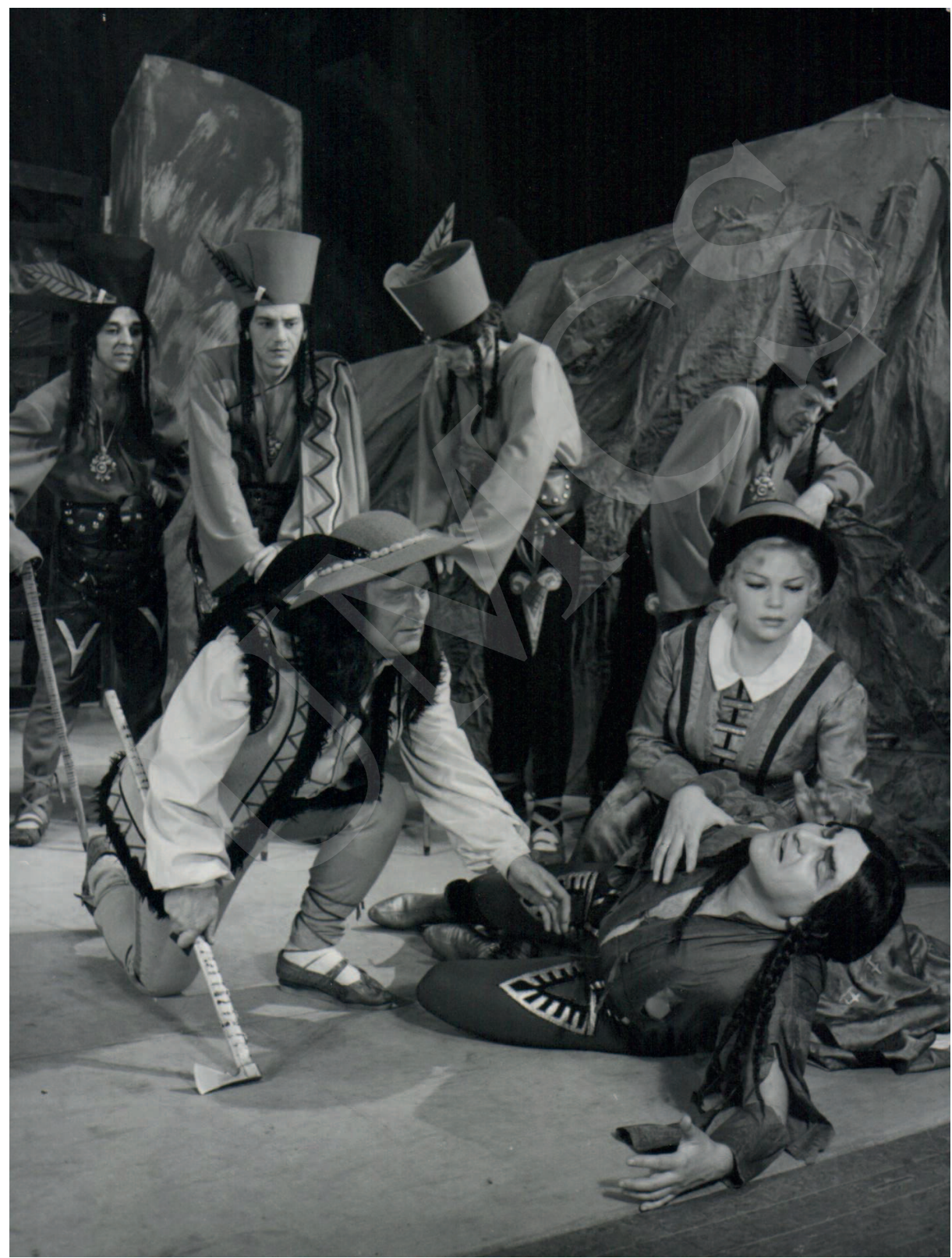

Ilustracja 3. Bolesław Wallek Walewski Pomsta Jontkowa, premiera w Operze Wrocławskiej 23 XI 1970, od lewej: Adam Dachtera (Jontek), Krystyna Czaplarska (Helena), Tadeusz Prochowski (Janosik) oraz Artyści Chóru Opery Wrocławskiej, Archiwum Opery Wrocławskiej, nr sygn. 108. 
Wszechstronna działalność Bolesława Wallek Walewskiego jako dyrygenta zespołów chóralnych, organizatora instytucji kulturalnych, kompozytora i krytyka muzycznego (pisał artykuły i recenzje muzyczne w czasopismach „Nowa Reforma”, „Czas”, „Głos Narodu” i „Gazeta Literacka”) miała duże znaczenie dla rozwoju życia muzycznego Krakowa. Po śmierci Władysława Żeleńskiego w 1921 roku był on najwybitniejszym kompozytorem działającym w środowisku muzycznym tego miasta. Odnosił sukcesy jako dyrygent, a prowadzony przezeń chór „Echo”, którym dyrygował na licznych koncertach w kraju i za granicą, należał do najlepszych amatorskich zespołów wokalnych w kraju. Ważną inicjatywą kulturalną było założenie Krakowskiego Towarzystwa Operowego, które organizowało przedstawienia z udziałem wybitnych śpiewaków, m.in. gościnnie występujących Ady Sari, Jana Kiepury czy Adama Didura.

Znaczenie Pomsty Jontkowej w historii muzyki polskiej polega na oryginalnej idei skomponowania dzieła będącego kontynuacją najsłynniejszej polskiej opery. Mimo długiego okresu 68 lat, jaki upłynął od warszawskiej premiery 4-aktowej Halki do poznańskiej premiery Pomsty Jontkowej, powstało dzieło wybitne, unikatowe w polskiej literaturze muzycznej, które przyniosło kompozytorowi zasłużony sukces. W muzyce europejskiej pojawiają się przykłady dwóch słynnych oper powiązanych tematycznie, ale skomponowanych przez dwóch różnych kompozytorów. Są nimi, przykładowo, Wesele Figara Wolfganga Amadeusza Mozarta oraz powstały 30 lat później Cyrulik sewilski Gioacchina Rossiniego, jednak obydwa dzieła łączy postać Pierre'a Beaumarchais, na podstawie którego sztuk napisane były libretta tych oper. W przypadku Pomsty Jontkowej zarówno libretto, jak i muzyka były dziełem oryginalnym kompozytora. Mimo różnic w indywidualnym stylu muzycznym Moniuszki i Wallek Walewskiego, Halkę i Pomstę Jontkowa łączy przede wszystkim barwny koloryt góralskiego folkloru, idea konfliktów społecznych oraz dramatyczne losy głównych bohaterów. Sukces wystawień obu dzieł w ramach Opery Górskiej w Zakopanem świadczy, iż zamiar połączenia tych utworów w cykl był przedsięwzięciem ze wszech miar udanym. Pomsta Jontkowa to jedna z najbardziej oryginalnych polskich oper okresu międzywojennego. Łączy ona elementy tradycyjne z nowoczesnymi. Jest przejawem późnych inspiracji muzyką i estetyką Wagnera w muzyce polskiej, ale nawiązuje także do najlepszych tradycji polskiej opery narodowej. Nowatorską ideą było połączenie $\mathrm{w}$ operze cech impresjonistycznych z wprowadzeniem w szerokim zakresie stylizacji góralskiego folkloru. 


\section{SUMMARY}

Born in Lvov but first of all associated with the musical circles in Krakow, Bolesław Wallek Walewski (1885-1944) referred to one of Stanisław Moniuszko's most famous operas - Halka [Helen] - when composing his own opera Pomsta Jontkowa [Jontek's Vengeance] (1924). The contemporaries regarded Halka and Pomsta Jontkowa as a series. Both operas share common elements: Halka (Warsaw version) and Pomsta Jontkowa are four-act operas, the same characters appear in their librettos (Jontek, Zofia), and in both works the conflicts between the gentry and the peasants are highly important. The musical connections between the operas are evidenced by Walewski's use of the leading motifs. Moreover, both in Halka and in Pomsta Jontkowa, there are highlanders' dances. Walewski also includes melodies from Halka into his work.

The principal difference between the two operas is determined by three elements: the language of the librettos, the main dramatic assumptions, and the musical style. The libretto of Halka was written by Włodzimierz Wolski (1824-1882) without references to dialectal elements whereas Walewski liberally used the Podhale highlanders' dialect in his libretto. Moreover, unlike Halka, which emphasizes the personal experiences of the main heroine and social conflicts, the axis of Walewski's drama is the motif of the highlander's revenge on the wealthy lords. The musical style of Pomsta Jontkowa shows, on the one hand, a similarity with Richard Wagner's music (harmony, instrumentation, and the way of treatment of leitmotifs), while on the other - a similarity to the trend of musical folklorism and impressionism. An innovative idea is the combination of impressionist features with the stylization of highlanders' folklore.

Pomsta Jontkowa was the best known opera of the Krakow composer in Poland in the nineteen-twenties and thirties, and at the same time it was one of the most original Polish operas of the interwar period. It combines traditional elements with modern ones, and it is an expression of the late inspirations by Wagnerian music and esthetics in Polish music, as well as referring to the best traditions of the Polish national opera. 